\title{
Standardized ileal digestibility of amino acids in cereal grains and co-products in growing pigs
}

\author{
Su A Lee ${ }^{1,2}$, Jong Young Ahn ${ }^{1}$, Ah Reum Son ${ }^{3}$, and Beob Gyun Kim ${ }^{1,3, *}$
}

* Corresponding Author: Beob Gyun Kim Tel: +82-2-2049-6255, Fax: +82-2-455-1044, E-mail: bgkim@konkuk.ac.kr

${ }^{1}$ Department of Animal Science and Technology, Konkuk University, Seoul 05029, Korea

2 Department of Animal Sciences, University of Illinois at Urbana-Champaign, Urbana, IL 61801, USA

${ }^{3}$ Monogastric Animal Feed Research Institute, Konkuk

University, Seoul 05029, Korea

ORCID

Su A Lee

https://orcid.org/0000-0001-9351-7196

Jong Young Ahn

https://orcid.org/0000-0001-7893-459X Ah Reum Son

https://orcid.org/0000-0003-3199-9796

Beob Gyun Kim

https://orcid.org/0000-0003-2097-717X

Submitted May 28, 2019; Revised Jul 3, 2019; Accepted Oct 30, 2019
Objective: The objective was to determine standardized ileal digestibility (SID) of crude protein $(\mathrm{CP})$ and amino acids (AA) in cereal grains and various co-products fed to growing pigs.

Methods: Ten feed ingredients tested were barley $(9.3 \% \mathrm{CP})$, lupin kernels $(31.1 \% \mathrm{CP})$, and wheat $(11.3 \% \mathrm{CP})$ as cereal grains, and 2 sources of corn gluten feed produced in China $(21.6 \% \mathrm{CP})$ and Korea $(24.6 \% \mathrm{CP})$, corn gluten meal (65.3\% CP), lupin hulls (11.6\% CP), rice bran $(14.5 \% \mathrm{CP})$, soybean meal $(44.8 \% \mathrm{CP})$, and wheat bran $(15.4 \% \mathrm{CP})$ as co-products. Ten experimental diets were formulated to contain each ingredient as a sole source of $\mathrm{N}$ and an $\mathrm{N}$-free diet was used to correct basal endogenous losses of CP and AA. All diets also contained $0.5 \% \mathrm{Cr}_{2} \mathrm{O}_{3}$ as an indigestible index. A replicated $11 \times 6$ incomplete Latin square design with 11 dietary treatments, 6 periods, and 22 animals was employed. Twenty-two barrows with an initial body weight of $64.6 \pm 4.9 \mathrm{~kg}$ were equipped with a T-cannula in the distal ileum. An experimental period consisted of a 4-d adaptation period and a 2-d collection period.

Results: The SID of CP in the barley, lupin kernels, wheat, 2 sources of corn gluten feed, corn gluten meal, lupin hulls, rice bran, soybean meal, and wheat bran were $84.7 \%, 90.5 \%$, $90.4 \%, 77.4 \%, 74.6 \%, 89.5 \%, 90.4 \%, 74.4 \%, 86.9 \%$, and $63.4 \%$ (standard error of the mean $[\mathrm{SEM}]=5.3, \mathrm{p}=0.006)$, respectively. The respective SID values of Lys were $75.5 \%, 88.4 \%$, $83.9 \%, 74.7 \%, 62.4 \%, 80.3 \%, 83.9 \%, 78.5 \%, 88.0 \%$, and $71.2 \%(\mathrm{SEM}=3.3, \mathrm{p}<0.001)$, and the SID values of Met were 83.6\%, 88.7\%, 89.4\%, 85.7\%, 78.3\%, 88.9\%, 89.4\%, 85.3\%, 91.1\%, and $77.0 \%(\mathrm{SEM}=2.4, \mathrm{p}<0.001)$, respectively.

Conclusion: The ileal digestibility of protein and amino acids varies among the feed ingredients fed to pigs.

Keywords: Alternative Feed Ingredient; Cereal Grains; Co-products; Digestibility; Swine

\section{INTRODUCTION}

Amino acids (AA) are crucial nutrients for the metabolism of pigs. An adequate amount of AA in swine diets based on an accurately determined digestible AA in feed ingredients is important. Ileal digestibility of AA has been measured for an accurate determination of biological availability of AA, and a partial rather than a total collection method using an index has been widely used [1]. The use of standardized ileal digestibility (SID) values enables an accurate formulation due to the additivity $[2,3]$ resulting in maximal $\mathrm{N}$ retention and reduced N excretion [4]. The use of SID of AA has been suggested by Stein et al [5] and the AA contents in feed ingredients and the requirement estimates are expressed based on the SID in swine diet formulation [6].

The prices of conventional feed ingredients including corn and soybean meal (SBM) show yearly fluctuation. For an economic advantage, alternative feed ingredients have been used to substitute the conventional feed ingredients [7,8]. Information on the SID of AA in the 
alternative feed ingredients is necessary to accurately formulate swine diets. However, data on the SID of AA in some feed ingredients including corn gluten feed, lupin hulls, and rice bran are limited in the literature [6]. Thus, the objective of the present study was to determine the SID of crude protein $(\mathrm{CP})$ and $\mathrm{AA}$ in the various feed ingredients for pigs.

\section{MATERIALS AND METHODS}

\section{Animal care}

The experimental procedure was approved by the Institutional Animal Care and Use Committee at Konkuk University (KU12127).

\section{Animals, experimental design, and diets}

The ileal digestibility of AA in the feed ingredients was determined by employing a replicated $11 \times 6$ incomplete Latin square design with 11 dietary treatments, 6 periods, and 22 animals [9]. Twenty-two barrows with an initial body weight (BW) of $64.6 \pm 4.9 \mathrm{~kg}$ were equipped with a T-cannula in the distal ileum using the procedures adapted from Stein et al [10], and were individually housed.

Ten feed ingredients were used including barley, lupin kernels, and wheat as cereal grains, 2 sources of corn gluten feed produced in China (corn gluten feed-C) and Republic of Korea (corn gluten feed-K), corn gluten meal, lupin hulls, rice bran, and wheat bran as co-products, and SBM as a reference ingredient for AA digestibility (Table 1). Eleven experimental diets were prepared (Tables 2, 3). In addition to the 10 diets containing a test feed ingredient as the sole source of AA, an $\mathrm{N}$-free diet was also formulated based on cornstarch and sucrose to determine the basal endogenous losses (BEL) of CP and AA. In all diets, vitamin and mineral premix was also supplemented to meet or exceed the nutrient requirement estimates suggested by NRC [11]. All diets contained $0.5 \%$ $\mathrm{Cr}_{2} \mathrm{O}_{3}$ as an indigestible index [1].

\section{Feeding and sample collection}

The daily feed allowance per pig was 2.3 times the metabolizable energy $(\mathrm{ME})$ requirement for maintenance (i.e., $2.3 \times 106$

Table 1. Analyzed nutrient composition in feed ingredients (as-fed basis)

\begin{tabular}{|c|c|c|c|c|c|c|c|c|c|c|}
\hline Item (\%) & \multicolumn{3}{|c|}{ Cereal grains } & \multicolumn{7}{|c|}{ Co-products } \\
\hline Dry matter & 91.18 & 91.53 & 92.75 & 90.94 & 88.56 & 90.85 & 91.82 & 87.54 & 90.09 & 90.35 \\
\hline Crude protein & 9.32 & 31.13 & 11.30 & 21.56 & 24.55 & 65.25 & 11.58 & 14.51 & 44.80 & 15.43 \\
\hline Crude fiber & 4.35 & 6.46 & 2.44 & 9.93 & 7.23 & 1.43 & 39.56 & 6.14 & 4.82 & 7.68 \\
\hline Lys:crude protein & 4.40 & 5.82 & 3.36 & 3.38 & 3.37 & 1.81 & 5.95 & 5.66 & 6.88 & 4.42 \\
\hline \multicolumn{11}{|c|}{ Indispensable amino acids } \\
\hline $\operatorname{Arg}$ & 0.51 & 3.84 & 0.60 & 0.93 & 1.24 & 2.17 & 0.82 & 1.18 & 3.44 & 1.03 \\
\hline His & 0.22 & 0.99 & 0.29 & 0.64 & 0.77 & 1.37 & 0.29 & 0.43 & 1.28 & 0.43 \\
\hline Phe & 0.48 & 1.44 & 0.54 & 0.87 & 1.05 & 4.40 & 0.47 & 0.64 & 2.62 & 0.65 \\
\hline Thr & 0.35 & 1.37 & 0.36 & 0.78 & 0.90 & 2.41 & 0.44 & 0.57 & 1.98 & 0.53 \\
\hline Trp & 0.09 & 0.25 & 0.08 & 0.07 & 0.06 & 0.24 & 0.07 & 0.12 & 0.48 & 0.15 \\
\hline Val & 0.46 & 1.48 & 0.53 & 1.04 & 1.17 & 3.10 & 0.50 & 0.73 & 2.25 & 0.68 \\
\hline \multicolumn{11}{|l|}{ Dispensable amino acids } \\
\hline Ala & 0.42 & 1.32 & 0.46 & 1.61 & 1.73 & 6.04 & 0.46 & 0.89 & 2.14 & 0.75 \\
\hline Asp & 0.63 & 3.55 & 0.63 & 1.19 & 1.60 & 4.17 & 1.01 & 1.38 & 5.44 & 1.06 \\
\hline Cys & 0.27 & 0.56 & 0.35 & 0.56 & 0.71 & 1.47 & 0.18 & 0.37 & 0.88 & 0.40 \\
\hline Glu & 2.03 & 7.68 & 3.25 & 3.23 & 4.21 & 15.4 & 1.84 & 1.97 & 8.88 & 3.02 \\
\hline
\end{tabular}


Table 2. Ingredient composition of experimental diets (as-fed basis)

\begin{tabular}{|c|c|c|c|c|c|c|c|c|c|c|c|}
\hline \multirow[b]{3}{*}{ Item $(\%)$} & \multicolumn{11}{|c|}{ Diet } \\
\hline & \multicolumn{3}{|c|}{ Cereal grains } & \multicolumn{7}{|c|}{ Co-products } & \multirow[b]{2}{*}{$\mathrm{N}$-free } \\
\hline & Barley & $\begin{array}{l}\text { Lupin } \\
\text { kernels }\end{array}$ & Wheat & $\begin{array}{l}\text { Corn } \\
\text { gluten } \\
\text { feed- } \\
\text { China }\end{array}$ & $\begin{array}{l}\text { Corn } \\
\text { gluten } \\
\text { feed- } \\
\text { Korea }\end{array}$ & $\begin{array}{l}\text { Corn } \\
\text { gluten } \\
\text { meal }\end{array}$ & $\begin{array}{l}\text { Lupin } \\
\text { hulls }\end{array}$ & $\begin{array}{l}\text { Rice } \\
\text { bran }\end{array}$ & $\begin{array}{l}\text { Soybean } \\
\text { meal }\end{array}$ & $\begin{array}{c}\text { Wheat } \\
\text { bran }\end{array}$ & \\
\hline Corn starch & 27.15 & 37.20 & 27.15 & 37.35 & 37.20 & 50.50 & 37.50 & 27.40 & 44.15 & 27.45 & 68.35 \\
\hline Sucrose & 20.00 & 20.00 & 20.00 & 20.00 & 20.00 & 20.00 & 20.00 & 20.00 & 20.00 & 20.00 & 20.00 \\
\hline Barley & 50.00 & - & - & - & - & - & - & - & - & - & - \\
\hline Lupin kernels & - & 40.00 & - & - & - & - & - & - & - & - & - \\
\hline Wheat & - & - & 50.00 & - & - & - & - & - & - & - & - \\
\hline Corn gluten feed-China & - & - & - & 40.00 & - & - & - & - & - & - & - \\
\hline Corn gluten feed-Korea & - & - & - & - & 40.00 & - & - & - & - & - & - \\
\hline Corn gluten meal & - & - & - & - & - & 26.50 & - & - & - & - & - \\
\hline Lupin hulls & - & - & - & - & - & - & 40.00 & - & - & - & - \\
\hline Rice bran & - & - & - & - & - & - & - & 50.00 & - & - & - \\
\hline Soybean meal & - & - & - & - & - & - & - & - & 33.00 & - & - \\
\hline Wheat bran & - & - & - & - & - & - & - & - & - & 50.00 & - \\
\hline Soybean oil & - & - & - & - & - & - & - & - & - & - & 4.00 \\
\hline Cellulose & - & - & - & - & - & - & - & - & - & - & 4.00 \\
\hline $\mathrm{K}_{2} \mathrm{CO}_{3}$ & - & - & - & - & - & - & - & - & - & - & 0.40 \\
\hline $\mathrm{MgO}$ & - & - & - & - & - & - & - & - & - & - & 0.10 \\
\hline Ground limestone & 0.75 & 0.80 & 0.85 & 0.70 & 1.00 & 0.90 & 0.10 & 1.20 & 1.00 & 1.15 & 0.75 \\
\hline Dicalcium phosphate & 0.70 & 0.60 & 0.60 & 0.55 & 0.40 & 0.70 & 1.00 & - & 0.45 & - & 1.00 \\
\hline Salt & 0.40 & 0.40 & 0.40 & 0.40 & 0.40 & 0.40 & 0.40 & 0.40 & 0.40 & 0.40 & 0.40 \\
\hline Vitamin-mineral premix & 0.50 & 0.50 & 0.50 & 0.50 & 0.50 & 0.50 & 0.50 & 0.50 & 0.50 & 0.50 & 0.50 \\
\hline $\mathrm{Cr}_{2} \mathrm{O}_{3}$ & 0.50 & 0.50 & 0.50 & 0.50 & 0.50 & 0.50 & 0.50 & 0.50 & 0.50 & 0.50 & 0.50 \\
\hline
\end{tabular}

1) Provided the following quantities per $\mathrm{kg}$ of a diet: vitamin $\mathrm{A}, 25,000 \mathrm{IU}$; vitamin $\mathrm{D}_{31}$ 4,000 IU; vitamin $\mathrm{E}, 50 \mathrm{IU}$; vitamin $\mathrm{K}, 5.0 \mathrm{mg}$; thiamin, $4.9 \mathrm{mg}$; riboflavin, $10.0 \mathrm{mg}$; pyridoxine, $4.9 \mathrm{mg}$; vitamin $\mathrm{B}_{12}, 0.06 \mathrm{mg}$; pantothenic acid, $37.5 \mathrm{mg}$; folic acid, $1.10 \mathrm{mg}$; niacin, $62 \mathrm{mg}$; biotin, $0.06 \mathrm{mg} ; \mathrm{Cu}_{1} 25 \mathrm{mg}$ as CuSO; $\mathrm{Fe}_{4} 268 \mathrm{mg}$ as FeSO; $1,5.0 \mathrm{mg}$ as $\mathrm{KIO}_{3} ; \mathrm{Mn}, 125 \mathrm{mg}$ as $\mathrm{MnSO}_{4} ; \mathrm{Se}, 0.38 \mathrm{mg}$ as $\mathrm{Na}_{2} \mathrm{SeO}_{3} ; \mathrm{Zn}, 313 \mathrm{mg}$ as $\mathrm{ZnO}$; butylated hydroxytoluene, $50 \mathrm{mg}$.

$\mathrm{kcal}$ of $\mathrm{ME} / \mathrm{kg}$ of $\mathrm{BW}^{0.75}$ ) [11] based on a calculated ME of each diet and equally provided twice as meals at 0830 and $1630 \mathrm{~h}$. Water was freely available at all times.

An experimental period consisted of a 4-d adaptation period and a 2 -d collection period. The ileal digesta from pigs were collected from 0900 to $1630 \mathrm{~h}$ on the collection days by attaching a plastic bag with a wire to the cannula barrel of pigs. Sample bags were changed at least once every $30 \mathrm{~min}$ or whenever the bags were filled with digesta. The collected ileal digesta samples were immediately stored at $-20^{\circ} \mathrm{C}$ to prevent bacterial degradation of the AA. At the end of experiment, the samples were freeze-dried and ground before the analyses.

\section{Chemical analyses}

Based on the methods illustrated in AOAC International [12], the feed ingredient, diet, ileal digesta samples were analyzed for dry matter (DM; method 930.15) and CP (method 990.03), and AA concentrations were also analyzed by hydrolyzing with $6 \mathrm{~N} \mathrm{HCl}$ for $24 \mathrm{~h}$ at $110^{\circ} \mathrm{C}$ (method 994.12) except for sulfurcontaining AA (method 985.28) and Trp (method 988.15).
For Met and Cys, samples were analyzed as methionine sulfone and cysteic acid after cold performic acid oxidation before the acid hydrolysis. For analysis of Trp, samples were hydrolyzed using barium hydroxide. The experimental diets were analyzed for ether extract (method 920.39), crude fiber (method 978.10), ash (method 942.05), Ca (method 978.02), and $\mathrm{P}$ (method 946.06). Concentrations of $\mathrm{Cr}$ in the diets and ileal digesta samples were analyzed using UV/Vis spectrophotometer (Optizen 2120UV, Mecasys Inc., Deajeon, Korea). Neutral detergent fiber (NDF) and acid detergent fiber (ADF) in the feed ingredient samples were also analyzed using Ankom Technology methods 12 and 13, respectively (Ankom 200 Fiber Analyzer, Ankom Technology, Macedon, NY, USA). Both ADF and NDF were expressed inclusive of residual ash and NDF was assayed with a heat stable amylase.

\section{Calculations}

The apparent ileal digestibility (AID) and SID of CP and AA were calculated based on $\mathrm{CP}, \mathrm{AA}$, and $\mathrm{Cr}$ concentrations in diets and ileal digesta. Because each feed ingredient was the sole source of $\mathrm{N}$ in the experimental diets, the AID or SID of 
Table 3. Analyzed nutrient composition of experimental diets (as-fed basis)

\begin{tabular}{|c|c|c|c|c|c|c|c|c|c|c|c|}
\hline \multirow[b]{3}{*}{ Item (\%) } & \multicolumn{11}{|c|}{ Diet } \\
\hline & \multicolumn{3}{|c|}{ Cereal grains } & \multicolumn{7}{|c|}{ Co-products } & \multirow[b]{2}{*}{$\mathrm{N}$-free } \\
\hline & Barley & $\begin{array}{l}\text { Lupin } \\
\text { kernels }\end{array}$ & Wheat & $\begin{array}{l}\text { Corn gluten } \\
\text { feed-China }\end{array}$ & $\begin{array}{l}\text { Corn gluten } \\
\text { feed-Korea }\end{array}$ & $\begin{array}{c}\text { Corn } \\
\text { gluten } \\
\text { meal }\end{array}$ & $\begin{array}{l}\text { Lupin } \\
\text { hulls }\end{array}$ & $\begin{array}{l}\text { Rice } \\
\text { bran }\end{array}$ & $\begin{array}{l}\text { Soybean } \\
\text { meal }\end{array}$ & $\begin{array}{c}\text { Wheat } \\
\text { bran }\end{array}$ & \\
\hline Dry matter & 91.35 & 91.67 & 92.48 & 92.23 & 91.48 & 91.41 & 91.51 & 91.03 & 91.10 & 90.62 & 91.99 \\
\hline Crude protein & 5.22 & 12.17 & 5.97 & 8.66 & 10.83 & 19.89 & 3.94 & 8.19 & 15.49 & 7.96 & 0.48 \\
\hline Ether extract & 0.79 & 2.05 & 0.73 & 0.58 & 1.45 & 0.15 & 0.65 & 9.09 & 0.50 & 1.56 & 2.74 \\
\hline Crude fiber & 2.47 & 3.71 & 1.52 & 3.98 & 2.83 & 0.80 & 14.6 & 3.09 & 2.94 & 4.35 & 2.03 \\
\hline Ash & 3.68 & 3.65 & 3.53 & 4.55 & 5.84 & 3.06 & 3.35 & 6.60 & 4.80 & 4.69 & 3.53 \\
\hline $\mathrm{Ca}$ & 0.51 & 0.61 & 0.51 & 0.47 & 0.66 & 0.58 & 0.50 & 0.59 & 0.76 & 0.53 & 0.60 \\
\hline$P$ & 0.25 & 0.29 & 0.26 & 0.35 & 0.45 & 0.21 & 0.27 & 0.90 & 0.33 & 0.45 & 0.20 \\
\hline \multicolumn{12}{|c|}{ Indispensable amino acids } \\
\hline $\operatorname{Arg}$ & 0.22 & 1.36 & 0.30 & 0.37 & 0.43 & 0.53 & 0.24 & 0.53 & 1.09 & 0.54 & 0.01 \\
\hline His & 0.10 & 0.36 & 0.14 & 0.26 & 0.31 & 0.38 & 0.08 & 0.20 & 0.41 & 0.23 & - \\
\hline Ile & 0.14 & 0.50 & 0.20 & 0.27 & 0.35 & 0.73 & 0.12 & 0.22 & 0.69 & 0.26 & 0.01 \\
\hline Leu & 0.29 & 0.91 & 0.40 & 0.78 & 0.99 & 3.19 & 0.22 & 0.45 & 1.21 & 0.52 & 0.02 \\
\hline Lys & 0.18 & 0.63 & 0.20 & 0.30 & 0.32 & 0.33 & 0.21 & 0.39 & 0.97 & 0.38 & 0.01 \\
\hline Met & 0.07 & 0.11 & 0.11 & 0.12 & 0.13 & 0.40 & 0.05 & 0.14 & 0.21 & 0.13 & - \\
\hline Phe & 0.22 & 0.50 & 0.27 & 0.35 & 0.43 & 1.17 & 0.14 & 0.31 & 0.78 & 0.35 & 0.01 \\
\hline Thr & 0.16 & 0.49 & 0.19 & 0.33 & 0.34 & 0.65 & 0.14 & 0.27 & 0.64 & 0.29 & 0.01 \\
\hline Trp & 0.03 & 0.11 & 0.06 & 0.03 & 0.02 & 0.07 & 0.01 & 0.07 & 0.14 & 0.05 & - \\
\hline Val & 0.21 & 0.50 & 0.27 & 0.43 & 0.45 & 0.82 & 0.17 & 0.33 & 0.74 & 0.38 & 0.02 \\
\hline \multicolumn{12}{|c|}{ Dispensable amino acids } \\
\hline Ala & 0.19 & 0.45 & 0.24 & 0.65 & 0.65 & 1.62 & 0.15 & 0.41 & 0.70 & 0.41 & 0.01 \\
\hline Asp & 0.29 & 1.25 & 0.33 & 0.50 & 0.60 & 1.13 & 0.30 & 0.65 & 1.77 & 0.58 & 0.02 \\
\hline Cys & 0.11 & 0.25 & 0.17 & 0.23 & 0.23 & 0.37 & 0.09 & 0.20 & 0.28 & 0.21 & - \\
\hline Glu & 0.96 & 2.68 & 1.68 & 1.36 & 1.58 & 4.11 & 0.56 & 0.92 & 2.92 & 1.65 & 0.05 \\
\hline Gly & 0.19 & 0.57 & 0.25 & 0.39 & 0.40 & 0.50 & 0.15 & 0.36 & 0.67 & 0.44 & 0.01 \\
\hline Pro & 0.37 & 0.24 & 0.50 & 0.71 & 0.79 & 1.58 & 0.12 & 0.25 & 0.69 & 0.47 & 0.01 \\
\hline Ser & 0.19 & 0.61 & 0.28 & 0.36 & 0.40 & 0.96 & 0.18 & 0.30 & 0.79 & 0.36 & 0.02 \\
\hline Tyr & 0.11 & 0.41 & 0.14 & 0.20 & 0.26 & 0.68 & 0.10 & 0.19 & 0.46 & 0.22 & - \\
\hline
\end{tabular}

a diet was considered as the AID or SID in each feed ingredient. The AID of CP and AA were calculated based on the following equation [1]:

$$
\operatorname{AID}(\%)=\left[1-\left(\mathrm{Cr}_{\text {input }} / \mathrm{Cr}_{\text {oupput }}\right) \times\left(\mathrm{AA}_{\text {output }} / \mathrm{AA}_{\text {input }}\right)\right] \times 100
$$

where $\mathrm{Cr}_{\text {input }}$ and $\mathrm{Cr}_{\text {output }}$ represented the $\mathrm{Cr}$ concentrations $(\mathrm{g} / \mathrm{kg})$ in the diets and ileal digesta from pigs, respectively; $\mathrm{AA}_{\text {input }}$ and $\mathrm{AA}_{\text {ouput }}$ represented the $\mathrm{CP}$ or AA concentrations $(\mathrm{g} / \mathrm{kg})$ in the diets and ileal digesta from the pigs, respectively.

The BEL of CP and AA ( $\mathrm{g} / \mathrm{kg}$ of DM intake) were based on the following equation [1]:

$$
\begin{aligned}
& \text { BEL of CP and AA }(\mathrm{g} / \mathrm{kg} \text { of DM intake }) \\
& =\left(\mathrm{Cr}_{\text {input }} / \mathrm{Cr}_{\text {output }}\right) \times \mathrm{AA}_{\text {output }}
\end{aligned}
$$

where $\mathrm{Cr}_{\text {input }}$ and $\mathrm{Cr}_{\text {output }}$ represented the $\mathrm{Cr}$ concentrations ( $\mathrm{g} / \mathrm{kg}$ of $\mathrm{DM})$ in an $\mathrm{N}$-free diet and ileal digesta from pigs fed the $\mathrm{N}$-free diet, respectively; $\mathrm{AA}_{\text {ouput }}$ represented the $\mathrm{CP}$ or AA concentrations ( $\mathrm{g} / \mathrm{kg}$ of $\mathrm{DM})$ in the ileal digesta from pigs fed the $\mathrm{N}$-free diet.

The SID of CP and AA were calculated based on the following equation [1]:

$$
\operatorname{SID}(\%)=\operatorname{AID}(\%)+\left[100 \times\left(B E L / A_{\text {input }}\right)\right]
$$

\section{Statistical analysis}

Data were analyzed using the MIXED procedure of SAS (SAS Inst. Inc., Cary, NC, USA). An initial model included diet as a fixed effect and replication, period nested within replication, and animal nested within replication as random effects. The random variables were not significant and consequently were excluded from the final model. Least squares mean separation in the AID and SID of CP and AA among the feed ingredients was performed using the PDIFF option with Tukey's adjustment. The pig was the experimental unit, and significance was determined at $\mathrm{p}$-values less than 0.05 . 


\section{RESULTS}

\section{Nutrient composition}

The CP concentration in the feed ingredients used in the present study ranged from $9.3 \%$ to $65.3 \%$ (Table 1). Lysine:CP ratios that generally represent the quality of proteins in wheat and corn co-products were less than those in other feed ingredients. Analyzed CP and AA concentrations in the experimental diets except the lupin hull-containing diet agreed with the calculated values (Table 3 ).

\section{Apparent ileal digestibility of crude protein and amino} acids

The AID of CP and AA in the 10 feed ingredients differed from each other $(\mathrm{p}<0.05$; Table 4$)$. The AID of CP and indispensable AA in lupin kernels were greater $(\mathrm{p}<0.05)$ than those in barley and wheat except Arg, Lys, Met, and Trp. The AID of CP and AA in corn gluten meal and SBM did not differ from each other. The AID of Arg, Lys, and Trp in the 2 sources of corn gluten feeds were less $(p<0.05)$ compared with the values in SBM, and the AID of Ile, Leu, Phe, Thr, and Val in rice bran were also less $(\mathrm{p}<0.05)$ than the values in SBM. The AID values for $\mathrm{CP}$ and most $\mathrm{AA}$ in lupin hulls and wheat bran were less $(\mathrm{p}<0.05)$ than those in SBM.

\section{Standardized ileal digestibility of crude protein and amino acids}

The SID of CP and AA in the 11 feed ingredients differed from each other ( $p<0.05$; Table 5) except for Arg and Gly. The SID of $\mathrm{CP}$ and most AA in corn gluten feed-C, corn gluten meal, lupin hulls did not differ. The SID of Ile, Leu, Phe, and Val in rice bran were less $(\mathrm{p}<0.05)$ than other co-products except for wheat bran. The SID values of most indispensable AA in wheat bran were less than the values in the SBM $(\mathrm{p}<0.05)$.

\section{DISCUSSION}

The $\mathrm{CP}$ and most indispensable AA in barley, lupin kernels, corn gluten feed-C, SBM, and wheat bran agreed with the previous values $[6,13,14]$. The $\mathrm{CP}$ and most AA concentrations of wheat and rice bran used in the present study were less than those reported previously $[6,14,15]$, but similar to those in Sauvant et al [13]. The CP and AA concentrations in corn gluten feed-K and corn gluten meal were greater than the values presented by the literature $[6,13,14]$. The AA concentrations in lupin hulls used in this study were about twice

Table 4. Apparent ileal digestibility of crude protein and amino acids in feed ingredients

\begin{tabular}{|c|c|c|c|c|c|c|c|c|c|c|c|c|}
\hline \multirow[b]{2}{*}{ Item (\%) } & \multicolumn{3}{|c|}{ Cereal grains } & \multicolumn{7}{|c|}{ Co-products } & \multirow[b]{2}{*}{ SEM } & \multirow[b]{2}{*}{ p-value } \\
\hline & Barley & $\begin{array}{l}\text { Lupin } \\
\text { kernels }\end{array}$ & Wheat & $\begin{array}{l}\text { Corn gluten } \\
\text { feed-China }\end{array}$ & $\begin{array}{l}\text { Corn gluten } \\
\text { feed- Korea }\end{array}$ & $\begin{array}{c}\text { Corn } \\
\text { gluten } \\
\text { meal }\end{array}$ & $\begin{array}{l}\text { Lupin } \\
\text { hulls }\end{array}$ & $\begin{array}{l}\text { Rice } \\
\text { bran }\end{array}$ & $\begin{array}{c}\text { Soybean } \\
\text { meal }\end{array}$ & $\begin{array}{c}\text { Wheat } \\
\text { bran }\end{array}$ & & \\
\hline Observation (n) & 9 & 11 & 8 & 9 & 7 & 8 & 8 & 5 & 9 & 8 & - & - \\
\hline $\mathrm{CP}$ & $51.5^{c}$ & $75.9^{\mathrm{ab}}$ & $49.9^{c}$ & $55.3^{c}$ & $59.3^{\mathrm{bc}}$ & $80.5^{a}$ & $49.9^{c}$ & $59.9^{\mathrm{abc}}$ & $74.5^{\mathrm{ab}}$ & $43.4^{c}$ & 4.3 & $<0.001$ \\
\hline \multicolumn{13}{|l|}{ Indispensable AA } \\
\hline Arg & $60.4^{c}$ & $92.7^{\mathrm{a}}$ & $79.1^{\mathrm{ab}}$ & $71.9^{b c}$ & $70.0^{b c}$ & $79.9^{\mathrm{ab}}$ & $79.1^{\mathrm{ab}}$ & $83.4^{\mathrm{ab}}$ & $89.6^{a}$ & $81.8^{\mathrm{ab}}$ & 3.3 & $<0.001$ \\
\hline His & $68.3^{\text {cd }}$ & $86.8^{a}$ & $66.4^{d}$ & $78.2^{\mathrm{ab}}$ & $76.2^{\mathrm{bcd}}$ & $84.4^{\mathrm{ab}}$ & $66.4^{d}$ & $76.9^{\text {abcd }}$ & $86.4^{\mathrm{ab}}$ & $78.3^{\mathrm{abc}}$ & 2.3 & $<0.001$ \\
\hline lle & $53.6^{\text {cd }}$ & $83.2^{\mathrm{a}}$ & $59.6^{\text {cd }}$ & $67.6^{b c}$ & $69.5^{\mathrm{abc}}$ & $82.3^{\mathrm{ab}}$ & $59.6^{\mathrm{cd}}$ & $45.4^{d}$ & $81.0^{\mathrm{ab}}$ & $60.2^{\text {cd }}$ & 3.8 & $<0.001$ \\
\hline Leu & $64.9^{\text {cd }}$ & $85.3^{\mathrm{a}}$ & $65.7^{\text {cd }}$ & $82.0^{\mathrm{ab}}$ & $79.1^{a b}$ & $87.8^{\mathrm{a}}$ & $65.7^{\text {cd }}$ & $58.6^{d}$ & $82.9^{\mathrm{a}}$ & $66.7^{\mathrm{cd}}$ & 2.5 & $<0.001$ \\
\hline Lys & $59.3^{\mathrm{bc}}$ & $83.7^{\mathrm{a}}$ & $71.0^{\mathrm{ab}}$ & $64.1^{b c}$ & $53.7^{c}$ & $71.2^{\mathrm{ab}}$ & $71.0^{\mathrm{ab}}$ & $73.2^{\mathrm{ab}}$ & $84.7^{\mathrm{a}}$ & $64.0^{b c}$ & 3.5 & $<0.001$ \\
\hline Met & $74.0^{\mathrm{bc}}$ & $82.4^{\mathrm{abc}}$ & $77.0^{\mathrm{abc}}$ & $79.5^{a b c}$ & $73.3^{b c}$ & $87.1^{\mathrm{a}}$ & $77.0^{\mathrm{abc}}$ & $82.1^{a b c}$ & $87.5^{\mathrm{a}}$ & $72.2^{c}$ & 2.7 & $<0.001$ \\
\hline Phe & $70.8^{\text {cde }}$ & $84.1^{\mathrm{ab}}$ & $64.6^{\mathrm{de}}$ & $77.9^{\mathrm{abc}}$ & $73.7^{b c d}$ & $86.1^{\mathrm{a}}$ & $64.6^{\mathrm{de}}$ & $60.3^{e}$ & $83.1^{a b}$ & $69.0^{\text {cde }}$ & 2.4 & $<0.001$ \\
\hline Thr & $45.3^{c}$ & $77.5^{\mathrm{a}}$ & $47.4^{c}$ & $59.3^{b c}$ & $52.4^{c}$ & $77.8^{\mathrm{a}}$ & $47.4^{c}$ & $47.4^{c}$ & $76.4^{\mathrm{ab}}$ & $47.0^{c}$ & 4.1 & $<0.001$ \\
\hline $\operatorname{Trp}$ & $56.4^{\mathrm{abc}}$ & $84.7^{\mathrm{a}}$ & $24.3^{\mathrm{cd}}$ & $43.5^{b c d}$ & $6.06^{d}$ & $75.4^{\mathrm{ab}}$ & $24.3^{\mathrm{cd}}$ & $63.4^{\mathrm{abc}}$ & $83.2^{\mathrm{a}}$ & $39.5^{\mathrm{bcd}}$ & 8.2 & $<0.001$ \\
\hline Val & $52.0^{d}$ & $75.7^{\mathrm{ab}}$ & $52.7^{d}$ & $69.5^{\mathrm{abc}}$ & $61.4^{\text {bcd }}$ & $79.8^{\mathrm{a}}$ & $52.7^{d}$ & $51.5^{d}$ & $77.2^{\mathrm{a}}$ & $54.8^{d}$ & 3.3 & $<0.001$ \\
\hline \multicolumn{13}{|l|}{ Dispensable AA } \\
\hline Ala & $43.9^{c}$ & $72.3^{\mathrm{ab}}$ & $47.7^{c}$ & $75.8^{\mathrm{ab}}$ & $69.6^{\mathrm{ab}}$ & $84.2^{\mathrm{a}}$ & $47.7^{c}$ & $58.0^{\mathrm{bc}}$ & $74.1^{\mathrm{ab}}$ & $48.5^{c}$ & 4.1 & $<0.001$ \\
\hline Asp & $50.5^{c}$ & $83.0^{a}$ & $61.7^{c}$ & $60.4^{c}$ & $56.3^{c}$ & $79.2^{\mathrm{ab}}$ & $61.7^{c}$ & $63.6^{\mathrm{bc}}$ & $82.6^{a}$ & $57.4^{c}$ & 3.4 & $<0.001$ \\
\hline Cys & $60.3^{c d}$ & $82.9^{\mathrm{a}}$ & $70.5^{\mathrm{abcd}}$ & $62.0^{\text {bcd }}$ & $54.8^{d}$ & $77.1^{\mathrm{ab}}$ & $70.5^{\mathrm{abcd}}$ & $65.7^{\text {abcd }}$ & $74.6^{\mathrm{abc}}$ & $62.8^{\mathrm{bcd}}$ & 3.6 & $<0.001$ \\
\hline Glu & $79.0^{\text {cd }}$ & $89.5^{\mathrm{a}}$ & $75.4^{d}$ & $77.7^{d}$ & $75.4^{d}$ & $86.7^{\mathrm{abc}}$ & $75.4^{d}$ & $74.4^{d}$ & $86.4^{\mathrm{abc}}$ & $81.1^{\mathrm{bcd}}$ & 1.8 & $<0.001$ \\
\hline Gly & $0.87^{d}$ & $71.4^{\mathrm{a}}$ & $11.5^{\mathrm{cd}}$ & $32.7^{\text {bcd }}$ & $32.6^{b c d}$ & $58.1^{\mathrm{ab}}$ & $11.5^{\mathrm{cd}}$ & $40.8^{\mathrm{abcd}}$ & $60.7^{a b}$ & $46.5^{a b c}$ & 8.7 & $<0.001$ \\
\hline Pro & $-78.8^{\mathrm{ab}}$ & $-59.1^{a b}$ & $-177^{b}$ & $-23.5^{a b}$ & $7.78^{\mathrm{ab}}$ & $55.9^{\mathrm{a}}$ & $-177^{b}$ & $-124^{a b}$ & $0.14^{\mathrm{ab}}$ & $-28.7^{a b}$ & 44.7 & 0.032 \\
\hline Ser & $53.9^{c}$ & $81.8^{a}$ & $57.8^{\mathrm{bc}}$ & $65.5^{b c}$ & $63.6^{b c}$ & $83.0^{a}$ & $57.8^{\mathrm{bc}}$ & $55.9^{b c}$ & $81.6^{a}$ & $62.2^{b c}$ & 2.9 & $<0.001$ \\
\hline Tyr & $58.6^{d}$ & $85.3^{\mathrm{a}}$ & $66.0^{d}$ & $68.1^{\mathrm{cd}}$ & $67.7^{\mathrm{bcd}}$ & $82.5^{a b}$ & $66.0^{d}$ & $61.7^{d}$ & $80.7^{\mathrm{abc}}$ & $64.7^{d}$ & 3.1 & $<0.001$ \\
\hline
\end{tabular}

$S E M$, standard error of the mean; $C P$, crude protein; $A A$, amino acids.

a-e Within a row, means without a common superscript differ $(p<0.05)$. 
Table 5. Standardized ileal digestibility of crude protein and amino acids in feed ingredients ${ }^{1)}$

\begin{tabular}{|c|c|c|c|c|c|c|c|c|c|c|c|c|}
\hline \multirow[b]{2}{*}{ Item (\%) } & \multicolumn{3}{|c|}{ Cereal grains } & \multicolumn{7}{|c|}{ Co-products } & \multirow[b]{2}{*}{ SEM } & \multirow[b]{2}{*}{$p$-value } \\
\hline & Barley & $\begin{array}{l}\text { Lupin } \\
\text { kernels }\end{array}$ & Wheat & $\begin{array}{l}\text { Corn gluten } \\
\text { feed-China }\end{array}$ & $\begin{array}{l}\text { Corn gluten } \\
\text { feed-Korea }\end{array}$ & $\begin{array}{c}\text { Corn gluten } \\
\text { meal }\end{array}$ & $\begin{array}{l}\text { Lupin } \\
\text { hulls }\end{array}$ & $\begin{array}{l}\text { Rice } \\
\text { bran }\end{array}$ & $\begin{array}{c}\text { Soybean } \\
\text { meal }\end{array}$ & $\begin{array}{c}\text { Wheat } \\
\text { bran }\end{array}$ & & \\
\hline Observation (n) & 9 & 11 & 8 & 9 & 7 & 8 & 8 & 5 & 9 & 8 & - & - \\
\hline $\begin{array}{l}\mathrm{CP} \\
\text { Indispensable AA }\end{array}$ & $84.7^{\mathrm{ab}}$ & $90.5^{a}$ & $90.4^{a}$ & $77.4^{\mathrm{ab}}$ & $74.6^{\mathrm{ab}}$ & $89.5^{\mathrm{a}}$ & $90.4^{a}$ & $74.4^{\mathrm{ab}}$ & $86.9^{a b}$ & $63.4^{b}$ & 5.3 & 0.006 \\
\hline $\operatorname{Arg}$ & 86.9 & 97.2 & 99.8 & 90.6 & 82.5 & 91.7 & 99.8 & 88.1 & 95.9 & 91.0 & 4.5 & 0.238 \\
\hline His & 83.0 & 91.0 & 83.5 & 84.3 & 80.8 & 88.4 & 83.5 & 82.3 & 90.3 & 84.2 & 2.4 & 0.016 \\
\hline lle & $77.0^{\mathrm{abc}}$ & $89.8^{\mathrm{a}}$ & $86.3^{\mathrm{ab}}$ & $80.1^{\mathrm{ab}}$ & $78.8^{\mathrm{abc}}$ & $86.8^{\mathrm{ab}}$ & $86.3^{\mathrm{ab}}$ & $59.0^{c}$ & $85.9^{\mathrm{ab}}$ & $72.5^{b c}$ & 3.9 & $<0.001$ \\
\hline Leu & $80.0^{\mathrm{abc}}$ & $90.2^{\mathrm{a}}$ & $85.1^{\mathrm{ab}}$ & $87.8^{\mathrm{a}}$ & $83.4^{\mathrm{ab}}$ & $89.2^{a}$ & $85.1^{\mathrm{ab}}$ & $67.3^{c}$ & $86.7^{\mathrm{a}}$ & $74.9^{b c}$ & 2.6 & $<0.001$ \\
\hline Lys & $75.5^{\mathrm{abc}}$ & $88.4^{a}$ & $83.9^{a b}$ & $74.7^{\mathrm{abc}}$ & $62.4^{c}$ & $80.3^{\mathrm{ab}}$ & $83.9^{\mathrm{ab}}$ & $78.5^{\mathrm{abc}}$ & $88.0^{\mathrm{a}}$ & $71.2^{b c}$ & 3.3 & $<0.001$ \\
\hline Met & $83.6^{\mathrm{abc}}$ & $88.7^{\mathrm{ab}}$ & $89.4^{a b}$ & $85.7^{\mathrm{abc}}$ & $78.3^{b c}$ & $88.9^{\mathrm{ab}}$ & $89.4^{\mathrm{ab}}$ & $85.3^{a b c}$ & $91.1^{\mathrm{a}}$ & $77.0^{c}$ & 2.4 & $<0.001$ \\
\hline Phe & $83.2^{\mathrm{ab}}$ & $89.6^{a}$ & $83.8^{\mathrm{ab}}$ & $85.9^{\mathrm{ab}}$ & $79.9^{\mathrm{abc}}$ & $88.5^{\mathrm{a}}$ & $83.8^{\mathrm{ab}}$ & $68.4^{c}$ & $86.7^{\mathrm{ab}}$ & $76.7^{\mathrm{bc}}$ & 2.4 & $<0.001$ \\
\hline Thr & $76.3^{\mathrm{abc}}$ & $87.7^{\mathrm{a}}$ & $81.7^{\mathrm{abc}}$ & $75.0^{\mathrm{abc}}$ & $66.7^{b c}$ & $85.5^{\mathrm{ab}}$ & $81.7^{\mathrm{abc}}$ & $63.5^{b c}$ & $84.4^{\mathrm{ab}}$ & $63.6^{c}$ & 4.3 & $<0.001$ \\
\hline $\operatorname{Trp}$ & $80.6^{\mathrm{ab}}$ & $91.5^{\mathrm{a}}$ & $92.8^{\mathrm{a}}$ & $69.6^{\mathrm{abc}}$ & $41.2^{x}$ & $86.1^{\mathrm{ab}}$ & $92.8^{\mathrm{a}}$ & $71.4^{\mathrm{abc}}$ & $88.8^{\mathrm{ab}}$ & $53.2^{b c}$ & 8.5 & $<0.001$ \\
\hline Val & $77.4^{\mathrm{abc}}$ & $86.5^{\mathrm{a}}$ & $82.7^{\mathrm{abc}}$ & $82.5^{\mathrm{ab}}$ & $72.9^{\mathrm{abc}}$ & $86.5^{\mathrm{a}}$ & $82.7^{\mathrm{abc}}$ & $65.0^{c}$ & $84.8^{\mathrm{a}}$ & $68.2^{\mathrm{bc}}$ & 3.4 & $<0.001$ \\
\hline Dispensable AA & & & & & & & & & & & & \\
\hline Ala & $75.2^{\mathrm{ab}}$ & $85.8^{\mathrm{a}}$ & $84.6^{a}$ & $85.8^{a}$ & $78.4^{\mathrm{ab}}$ & $88.0^{\mathrm{a}}$ & $84.6^{\mathrm{a}}$ & $68.5^{\mathrm{ab}}$ & $83.3^{a}$ & $62.0^{b}$ & 4.5 & $<0.001$ \\
\hline Asp & $73.4^{\mathrm{bc}}$ & $88.4^{a}$ & $82.6^{\mathrm{abc}}$ & $74.6^{\mathrm{abc}}$ & $67.0^{c}$ & $85.2^{\mathrm{ab}}$ & $82.6^{\mathrm{abc}}$ & $71.6^{\mathrm{abc}}$ & $86.6^{\mathrm{ab}}$ & $68.2^{c}$ & 3.6 & $<0.001$ \\
\hline Cys & $77.9^{\mathrm{abcd}}$ & $90.9^{\mathrm{a}}$ & $90.4^{\mathrm{a}}$ & $71.3^{\mathrm{cd}}$ & $62.9^{d}$ & $82.5^{\mathrm{abc}}$ & $90.4^{\mathrm{a}}$ & $72.5^{\mathrm{bcd}}$ & $82.2^{\mathrm{abc}}$ & $71.3^{\mathrm{cd}}$ & 3.3 & $<0.001$ \\
\hline Glu & $87.4^{\mathrm{abc}}$ & $92.5^{\mathrm{a}}$ & $88.9^{a b c}$ & $84.1^{\mathrm{bc}}$ & $80.3^{c}$ & $88.7^{\mathrm{abc}}$ & $88.9^{\mathrm{abc}}$ & $81.0^{\mathrm{bc}}$ & $89.4^{\mathrm{ab}}$ & $85.7^{\mathrm{abc}}$ & 1.9 & $<0.001$ \\
\hline Gly & 75.0 & 97.0 & 95.5 & 73.9 & 65.6 & 87.8 & 95.5 & 63.4 & 84.7 & 75.2 & 12.1 & 0.529 \\
\hline Pro & $106^{\mathrm{ab}}$ & $237^{\mathrm{ab}}$ & $328^{\mathrm{a}}$ & $87.3^{b}$ & $88.6^{\mathrm{ab}}$ & $102^{\mathrm{ab}}$ & $328^{\mathrm{a}}$ & $24.9^{b}$ & $114^{\mathrm{ab}}$ & $100^{\mathrm{ab}}$ & 51.9 & 0.007 \\
\hline Ser & $80.2^{\mathrm{abc}}$ & $90.2^{\mathrm{a}}$ & $83.9^{a b c}$ & $80.4^{\mathrm{abc}}$ & $75.7^{\mathrm{abc}}$ & $88.4^{\mathrm{ab}}$ & $83.9^{\mathrm{abc}}$ & $68.7^{c}$ & $88.4^{\mathrm{ab}}$ & $75.3^{b c}$ & 3.3 & $<0.001$ \\
\hline Tyr & $78.9^{\mathrm{ab}}$ & $90.8^{a}$ & $87.8^{a b}$ & $79.6^{\mathrm{ab}}$ & $76.1^{b}$ & $85.8^{\mathrm{ab}}$ & $87.8^{\mathrm{ab}}$ & $72.4^{b}$ & $85.6^{\mathrm{ab}}$ & $74.6^{b}$ & 3.0 & $<0.001$ \\
\hline
\end{tabular}

SEM, standard error of the mean; CP, crude protein; AA, amino acids; SID, standardized ileal digestibility.

1) Each SID of CP and AA was calculated by correcting apparent ileal digestibility of CP and AA for basal endogenous losses. Basal endogenous losses ( $\mathrm{g} / \mathrm{kg}$ dry matter intake) were determined based on the $\mathrm{Cr}, \mathrm{CP}$, and $\mathrm{AA}$ concentrations in the $\mathrm{N}$-free diet and the ileal digesta from pigs fed the N-free diet as: $\mathrm{CP}, 22.8 ; \mathrm{Arg}, 0.87$; His, 0.19; Ile, 0.38; Leu, 0.51; Lys, 0.38; Met, 0.09; Phe, 0.31; Thr, 0.55; Trp, 0.09; Val, 0.64; Ala, 0.76; Asp, 0.83; Cys, 0.25; Glu, 1.01; Gly, 1.96; Pro, 9.68; Ser, 0.63; Tyr, 0.26.

a-d Within a row, means without a common superscript differ $(p<0.05)$.

greater compared to the data reported by Fernández and Batterham [16]. The reason for these discrepancies in the nutrient compositions of co-products among studies may be explained by several factors including different variety, growing environment, and processing methods and conditions [14]. Information on the AA compositions or digestibility of lupin hulls was not available to be compared.

The BEL of CP and AA determined from the pigs fed the $\mathrm{N}$-free diet agreed with the previous studies $[7,17]$ and the predicted BEL using an equation suggested by Park et al [18]. The AID of Pro in some feed ingredients showed negative values if an experimental diet contained low Pro concentration, which may be associated with low Pro digestibility, resulting in a larger contribution from the BEL of Pro that originated from mostly mucin and enzyme secretions to the ileal digesta $[19,20]$. The observation that the BEL of Pro was the greatest among other AA resulted also in large difference between the AID and SID of Pro in the feed ingredients.

The SID of most AA and CP in feed ingredients tested in this study were within a range of data in the literature $[6,13$, 14]. The SID of CP and AA in SBM used in the present study were similar to the values presented in the reviews of the literature $[6,13,14]$ and the recent publications $[21,22]$. The SID of most AA and CP in barley $[23,24]$ and wheat $[25,26]$ were within a range of data in recent publications. Almeida et al [27] reported the SID values of AA in the co-products of corn fed to pigs, and the SID values were similar compared to the values in the corn gluten feed-C and- $\mathrm{K}$ in the present study. The SID of CP and AA in corn gluten meal used in the present study were within a range of data in the literature $[27,28]$. While corn gluten feed and corn gluten meal were the co-products from corn, the SID values were variable between the sources, which may be explained by different concentrations of corn fractions [29]. The SID of CP and AA in lupin hulls was similar to that in SBM. To our knowledge, there have been no data on the SID of AA in lupin hulls reported previously. For rice bran, the SID of CP and AA observed in the present study was less than the values reported by Casas et al [15], but greater than the values by Huang et al [30]. There were variations in the $\mathrm{CP}$ and $\mathrm{AA}$ contents in the full fat rice bran used among the experiments, but the SID values are not be affected by the total contents of $\mathrm{CP}$ and AA [5]. The greater 
fat contents in rice bran may increase the greater AA digestibility in pigs [31,32], but the crude fat concentrations in the rice bran were similar among the sources used in the present study and the previous studies. The difference in fiber contents may also affect the AA digestibility in rice bran. It is possible that dietary NDF can decrease the digestibility of CP [33], and the NDF contents in rice bran were 21.4\% DM in the present study (Table 1) whereas the NDF in rice bran was $23.8 \% \mathrm{DM}$ [30] and 5.1\% DM [15], respectively. The SID in wheat bran used in this study was in agreement with the values reported by Eklund et al [25].

\section{CONCLUSION}

The values for the protein and AA digestibility in various feed ingredients in this study will be useful for the accurate formulation of swine diets. The ileal digestibility of protein and AAs varies among the feed ingredients fed to pigs.

\section{CONFLICT OF INTEREST}

We certify that there is no conflict of interest with any financial organization regarding the material discussed in the manuscript.

\section{ACKNOWLEDGMENTS}

This work was supported by the Rural Development Administration (Republic of Korea; PJ907038). This paper was supported by the KU Research Professor Program of Konkuk University.

\section{REFERENCES}

1. Kong C, Adeola O. Evaluation of amino acid and energy utilization in feedstuff for swine and poultry diets. AsianAustralas J Anim Sci 2014;27:917-25. https://doi.org/10.5713/ ajas.2014.r.02

2. Stein HH, Pedersen C, Wirt AR, Bohlke RA. Additivity of values for apparent and standardized ileal digestibility of amino acids in mixed diets fed to growing pigs. J Anim Sci 2005;83: 2387-95. https://doi.org/10.2527/2005.83102387x

3. Xue PC, Ragland D, Adeola O. Determination of additivity of apparent and standardized ileal digestibility of amino acids in diets containing multiple protein sources fed to growing pigs. J Anim Sci 2014;92:3937-44. https://doi.org/10.2527/ jas.2014-7815

4. Lee SA, Jo H, Kong C, Kim BG. Use of digestible rather than total amino acid in diet formulation increases nitrogen retention and reduces nitrogen excretion from pigs. Livest Sci 2017; 197:8-11. https://doi.org/10.1016/j.livsci.2016.12.013

5. Stein HH, Sève B, Fuller MF, Moughan PJ, de Lange CFM.
Invited review: Amino acid bioavailability and digestibility in pig feed ingredients: Terminology and application. J Anim Sci 2007;85:172-80. https://doi.org/10.2527/jas.2005-742

6. NRC. Committee on nutrient requirements of swine. Nutrient requirements of swine. 11th rev. ed. Washington, DC, USA: National Academy Press; 2012.

7. Son AR, Hyun Y, Htoo JK, Kim BG. Amino acid digestibility in copra expellers and palm kernel expellers by growing pigs. Anim Feed Sci Technol 2014;187:91-7. https://doi.org/10. 1016/j.anifeedsci.2013.09.015

8. Liu JD, Li QY, Zeng ZK, et al. Determination and prediction of the amino acid digestibility of sunflower seed meals in growing pigs. Asian-Australas J Anim Sci 2015;28:86-94. https://doi.org/10.5713/ajas.14.0109

9. Kim BG, Stein HH. A spreadsheet program for making a balanced Latin Square design. Rev Colom Cienc Pecu 2009; 22:591-6.

10. Stein HH, Shipley CF, Easter RA. Technical note: A technique for inserting a T-cannula into the distal ileum of pregnant sows. J Anim Sci 1998;76:1433-6. https://doi.org/10.2527/ 1998.7651433x

11.NRC. Committee on nutrient requirements of swine. Nutrient requirements of swine. 10th rev. ed. Washington, DC, USA: National Academy Press; 1998.

12. Horwitz W, Latimer GW. Official methods of analysis of AOAC International. 18th ed. Gaithersburg, MD, USA: AOAC International; 2005.

13. Sauvant D, Perez JM, Tran G. Tables of composition and nutritional value of feed materials: pigs, poultry, cattle, sheep, goats, rabbits, horses and fish. 2nd ed. Wageningen, The Netherlands: Wageningen Academic Publishers; 2004.

14. Stein HH, Lagos LV, Casas GA. Nutritional value of feed ingredients of plant origin fed to pigs. Anim Feed Sci Technol 2016;218:33-69. https://doi.org/10.1016/j.anifeedsci.2016. 05.003

15. Casas GA, Almeida JAS, Stein HH. Amino acid digestibility in rice co-products fed to growing pigs. Anim Feed Sci Technol 2015;207:150-8. https://doi.org/10.1016/j.anifeedsci.2015. 05.024

16. Fernández JA, Batterham ES. The nutritive value of lupin-seed and dehulled lupin-seed meals as protein sources for growing pigs as evaluated by different techniques. Anim Feed Sci Technol 1995;53:279-96. https://doi.org/10.1016/0377-8401 (94)00743-S

17. Kil DY, Park CS, Son AR, Ji SY, Kim BG. Digestibility of crude protein and amino acids in corn grains from different origins for pigs. Anim Feed Sci Technol 2014;196:68-75. https://doi. org/10.1016/j.anifeedsci.2014.06.008

18. Park CS, Oh SI, Kim BG. Prediction of basal endogenous losses of amino acids based on body weight and feed intake in pigs fed nitrogen-free diets. Rev Colom Cienc Pecua 2013; 26:186-92. 
19. Stein HH, Trottier NL, Bellaver C, Easter RA. The effect of feeding level and physiological status on total flow and amino acid composition of endogenous protein at the distal ileum in swine. J Anim Sci 1999;77:1180-7. https://doi.org/10.2527/ 1999.7751180x

20. Cervantes-Pahm SK, Liu Y, Evans A, Stein HH. Effect of novel fiber ingredients on ileal and total tract digestibility of energy and nutrients in semi-purified diets fed to growing pigs. J Sci Food Agric 2014;94:1284-90. https://doi.org/10.1002/ jsfa.6405

21.Park CS, Helmbrecht A, Htoo JK, Adeola O. Comparison of amino acid digestibility in full-fat soybean, two soybean meals, and peanut flour between broiler chickens and growing pigs. J Anim Sci 2017;95:3110-9. https://doi.org/10.2527/jas.2017. 1404

22. Son AR, Park CS, Park KR, Kim BG. Amino acid digestibility in plant protein sources fed to growing pigs. Asian-Australas J Anim Sci 2019;32:1745-52. https://doi.org/10.5713/ajas.19. 0037

23. Brestenský M, Nitrayová S, Patráš P, Heger J. Standardized ileal digestibilities of amino acids and nitrogen in rye, barley, soybean meal, malt sprouts, sorghum, wheat germ and broken rice fed to growing pigs. Anim Feed Sci Technol 2013;186: 120-4. https://doi.org/10.1016/j.anifeedsci.2013.09.006

24. Wang HL, Shi M, Xu X, Ma XK, Liu L, Piao XS. Comparative energy content and amino acid digestibility of barley obtained from diverse sources fed to growing pigs. Asian-Australas J Anim Sci 2017;30:999-1005. https://doi.org/10.5713/ajas.16. 0775

25.Eklund M, Rademacher M, Sauer WC, Blank R, Mosenthin R. Standardized ileal digestibility of amino acids in alfalfa meal, sugar beet pulp, and wheat bran compared to wheat and protein ingredients for growing pigs. J Anim Sci 2014;92: 1037-43. https://doi.org/10.2527/jas.2013-6436

26. Wang T, Osho SO, Adeola O. Additivity of apparent and stan- dardized ileal digestibility of amino acid determined by chromic oxide and titanium dioxide in mixed diets containing wheat and multiple protein sources fed to growing pigs. J Anim Sci 2018;96:4731-42. https://doi.org/10.1093/jas/ sky326

27. Almeida FN, Petersen GI, Stein HH. Digestibility of amino acids in corn, corn coproducts, and bakery meal fed to growing pigs. J Anim Sci 2011;89:4109-15. https://doi.org/10.2527/ jas.2011-4143

28. Ji Y, Zuo L, Wang FL, Li DF, Lai CH. Nutritional value of 15 corn gluten meals for growing pigs: chemical composition, energy content and amino acid digestibility. Arch Anim Nutr 2012;66:283-302. https://doi.org/10.1080/03235408.2012.70 2466

29.Loy DD, Lundy EL. Chapter 23 - Nutritional properties and feeding value of corn and its coproducts. In: Serna-Saldivar SO, editor. Corn (Third ed). Oxford, UK: AACC International Press; 2019. p. 633-59.

30.Huang C, Ma D, Zang J, et al. Effect of keratinase on ileal amino acid digestibility in five feedstuffs fed to growing pigs. Asian-Australas J Anim Sci 2018;31:1946-55. https://doi.org/ 10.5713/ajas.17.0815

31. Kaufmann C, Sauer WC, Cervantes M, et al. Amino acid and energy digestibility in different sources of rice bran for growing pigs. Can J Anim Sci 2005;85:355-63. https://doi.org/10. 4141/A04-084

32. Kil DY, Stein HH. Dietary soybean oil and choice white grease improve apparent ileal digestibility of amino acids in swine diets containing corn, soybean meal, and distillers dried grains with solubles. Rev Colom Cienc Pecua 2011;24:248-53.

33. Schulze H, Van leeuwen P, Verstegen MWA, Huisman J, Souffrant WB, Ahrens F. Effect of level of dietary neutral detergent fiber on ileal apparent digestibility and ileal nitrogen losses in pigs. J Anim Sci 1994;72:2362-8. https://doi.org/10. 2527/1994.7292362x 